\title{
Retrospective cohort study of anti-tumor necrosis factor agent use in a Veteran Population
}

Introduction: Anti-tumor necrosis factor (TNF) agents are effective for several immunologic conditions (rheumatoid arthritis (RA), Crohn's disease (CD), and psoriasis). The purpose of this study was to evaluate the efficacy and safety of anti-TNF agents via chart review. Methods: Single-site, retrospective cohort study that evaluated the efficacy and safety of anti-TNF agents in veterans initiated between 2010-2011. Primary aim evaluated response at 12 months post-index date. Secondary aims evaluated initial response prior to 12 months post-index date and infection events. Results: A majority of patients were prescribed antiTNF agents for CD (27\%) and RA (24\%). Patients were initiated on etanercept (41\%), adalimumab (40\%), and infliximab (18\%) between 2010-2011. No differences in patient demographics were reported. Response rates were high overall. Sixty-five percent of etanercept patients, $82 \%$ of adalimumab patients, and $59 \%$ of infliximab patients were either partial or full responders, respectively. Approximately $16 \% 11 \%$, and $12 \%$ of etanercept, adalimumab, and infliximab were non-responders, respectively. Infections between the groups were non-significant. Etanercept and adalimumab patients had higher but nonsignificant odds of being a responder relative to infliximab. Conclusions: Most patients initiated with anti-TNF agent were responders at 12 months follow-up for all indications in a veteran population. 
2

Title:

Retrospective cohort study of anti-tumor necrosis factor agent use in a Veteran Population

\author{
Authors: \\ Mark Bounthavong, Pharm.D.* \\ Pharmacoeconomics Clinical Specialist \\ Veterans Affairs San Diego Healthcare System
}

Nermeen Madkour, Pharm.D.

Biologics/Pharmacoeconomics Clinical Specialist

Veterans Affairs San Diego Healthcare System

Rashid Kazerooni, Pharm.D., BCPS

Pharmacoeconomics Clinical Specialist

Veterans Affairs San Diego Healthcare System

14 *Corresponding author:

15 Mark Bounthavong, Pharm.D.

163350 La Jolla Village Drive (119)

17 San Diego, CA 92161

18 Cell: 213-268-5425

19 Email: mbounthavong@outlook.com 
Disclosures

21 Dr. Bounthavong has received a grant from UCB pharmaceuticals, which is the manufacturer of 22 Cimzia (certolizumab pegol). IIS \#: 002296

23 Drs. Madkour and Kazerooni declare that there are no conflicts of interest regarding the 24 publication of this article. 


\section{Abstract:}

Introduction: Anti-tumor necrosis factor (TNF) agents are effective for several immunologic conditions (rheumatoid arthritis (RA), Crohn's disease (CD), and psoriasis). The purpose of this study was to evaluate the efficacy and safety of anti-TNF agents via chart review.

Methods: Single-site, retrospective cohort study that evaluated the efficacy and safety of antiTNF agents in veterans initiated between 2010-2011. Primary aim evaluated response at 12 months post-index date. Secondary aims evaluated initial response prior to 12 months post-index date and infection events.

Results: A majority of patients were prescribed anti-TNF agents for CD (27\%) and RA (24\%). Patients were initiated on etanercept (41\%), adalimumab (40\%), and infliximab (18\%) between 2010-2011. No differences in patient demographics were reported. Response rates were high overall. Sixty-five percent of etanercept patients, $82 \%$ of adalimumab patients, and $59 \%$ of infliximab patients were either partial or full responders, respectively. Approximately $16 \% 11 \%$, and $12 \%$ of etanercept, adalimumab, and infliximab were non-responders, respectively. Infections between the groups were non-significant. Etanercept and adalimumab patients had higher but non-significant odds of being a responder relative to infliximab.

Conclusions: Most patients initiated with anti-TNF agent were responders at 12 months followup for all indications in a veteran population. 


\section{Introduction:}

In the past two decades, biologic therapies have reshaped how clinicians approached chronic disease management (Agarwal, 2011a, 2011b; Ford et al., 2011; Lichtenstein et al., 2009;

Mayberry et al., 2013; Singh and Cameron, 2012). Immunologic disorders such as rheumatoid arthritis (RA) and Crohn's disease (CD) have traditionally relied on oral pharmacotherapy for treatment of acute symptoms, management, and remission. However, oral therapies were unable to provide long-term control and disease progression resulting in relapse and hospital admission/surgery. Biologic agents, such as monoclonal antibodies, target the host's immune system to attenuate the self-destructive immune response, which is the cause of RA and CD. Clinical efficacy with biologics has been reported in RA and CD as well as a reduction in hospital admission/surgery (Bodger, 2002; Lundkvist et al., 2008). More importantly, biologic therapy has improved the quality of life for patients suffering with these chronic diseases (Feagan et al., 2009; Staples et al., 2011).

Monoclonal antibodies, in particular, the anti-tumor necrosis factor (TNF) agents, have demonstrated significant reductions in disease symptoms, progression, and improvement in patient quality of life (Feagan et al., 2009; Ford et al., 2011; Lundkvist et al., 2008; Nixon et al., 2007; Ordás et al., 2011). In several studies, anti-TNF agents have increased the proportion of patients who experience remission; thereby, controlling the disease and limiting permanent damage. In some studies, remission duration has been reported for several years (Ancuța et al., 2009; Emery et al., 2010; van der Heijde et al., 2006).

RA is a systemic autoimmune disorder which is characterized by inflammation of the synovial joints (Segal et al., 2008). RA affects about $0.5 \%$ to $1.0 \%$ of the US population with a prevalence of 1.3 million (Gabriel and Michaud, 2009; Helmick et al., 2008). The health burden of RA in the 
US was estimated to be 98 Disability Adjusted Life Years (DALYS) lost per 100,000 population; and 1 RA-related death per 100,000 population (Lundkvist et al., 2008). In the VA, there were a total of 1,694 RA-related mortalities from 1999 to 2004 (Lee et al., 2007). The age-adjusted 5year RA-related mortality rate among patients with a single condition relative to no other condition was 6.05 (95\% confidence interval [CI]: 4.90, 7.20) (Lee et al., 2007). The average annual costs of RA per person in the US was \$12,558 (adjusted for 2006 \$US) (Lundkvist et al., 2008).

The goal of therapy for patients with RA is to control and reduce the rate of degeneration of the joints due to immunologic destruction by the host's immune system (Agarwal, 2011a). In addition, quality of life and increased productivity are important milestones for treatment. AntiTNF agents have been reported to reduce the rate of radiographic progression and improve shortterm inflammatory symptoms (Bathon et al., 2000; Breedveld et al., 2006; Choy et al., 2012; Emery et al., 2009; Keystone et al., 2008, 2009, 2004; Klareskog et al., 2004; Maini et al., 1999; Moreland et al., 1999; St Clair et al., 2004; van de Putte et al., 2004; Weinblatt et al., 2003, 1999). Consequently, improvement in clinical outcomes has resulted in improved quality of life for RA patients. To date, there are five FDA-approved anti-TNF agents for RA: adalimumab (Humira $\left.{ }^{\circledR}\right)$, certolizumab pegol (Cimzia $\left.{ }^{\circledR}\right)$, etanercept (Enbrel $\left.{ }^{\circledR}\right)$, golimumab (Simponi $\left.{ }^{\circledR}\right)$, and infliximab (Remicade®) (Agarwal, 2011b).

Crohn's disease is a chronic inflammation of the gastrointestinal tract that is characterized by abdominal pain, diarrhea, gastrointestinal bleeding, bowel perforations, and fistulas (Baumgart and Sandborn, 2012). The incidence of Crohn's disease in the United States (US) was 7.9 cases per 100,000 population (1990-2000); and the adjusted prevalence was 174 per 100,000 population (2001) (Loftus et al., 2007, 2002). In 2009, the average annual age- and gender- 
adjusted incidence rate of CD among veterans was 33 per 100,000 population (range: 27 to 40)

(Hou et al., 2013). The age- and gender-adjusted point prevalence of CD among veterans was 287 per 100,000 population (Hou et al., 2013). Prior to the wide-spread use of anti-TNF agents, the average annual cost per patient in the US was estimated to be $\$ 19,237$ (adjusted for $2012 \$$ US) with surgery responsible for a majority of direct costs (55.8\%) (Bodger, 2002). However, after the widespread use of anti-TNF agents, the average annual cost per patient with CD was $\$ 13,699$ per year (adjusted for 2012 \$US) (Kappelman et al., 2008).

Biologic therapies, such as anti-TNF agents, for Crohn's disease have provided clinically meaningful improvement in patient reported outcomes while maintaining remission (Ford et al., 2011; Hanauer et al., 2006; Louis et al., 2013; Sandborn et al., 2007a, 2007b). As a result, the increased utilization of anti-TNF therapy has shifted costs from hospitalizations and surgeries to medications. Van der Valk, et al. (2012) reported that medication costs were responsible for $70.9 \%$ of total direct costs compared to hospitalizations- (19.4\%) and surgery-related costs (0.6\%) in the Netherlands (van der Valk et al., 2012). Loomes, et al. (2011) reported that total direct costs increased from $\$ 3,930$ to $\$ 25,346$ (difference of $\$ 21,416, \mathrm{P}<0.005$ ) after the introduction of infliximab therapy (adjusted for 2010 \$CAN) (Loomes et al., 2011). Currently, there are three anti-TNF agents FDA-approved for the treatment and management of CD: adalimumab (Humira), certolizumab pegol (Cimzia), and infliximab (Remicade) (FDA Office of the Commissioner, 2008; NIDDK National Digestive Diseases Information Clearinghouse, n.d.).

The Department of Veterans Affairs has a national formulary that is shared with all the VA medical centers around US and its territories. However, none of the anti-TNF agents are listed on the VA National Formulary (VANF) as of August 2013. This is important because the burden of 
111 disease in the VA is significant. There have been no reports that currently investigated the

112 efficacy and safety of anti-TNF agents in the veteran population for all indications.

113 The purpose of this study was to evaluate the efficacy and safety of anti-TNF agent use in the

114 Veterans Affairs San Diego Healthcare System (VASDHS) who initiated therapy in 2010 and

1152011 for all prescribed indications. Particular attention was focused on RA and CD due to early

116 approvals in these therapeutic areas. 


\section{Methods:}

This was a single-site, retrospective cohort study that evaluated the efficacy and safety of antiTNF agents in a veteran population who initiated treatment between 2010 and 2011 and followed-up for 12 months. The study site was at VASDHS, a 296-bed medical facility in the San Diego County, California with a regional patient membership of approximately 232,000 veterans. VASDHS is part of the Veterans Health Administration (VHA), an integrated healthcare system in the US.

Patients were eligible for inclusion if they were 18 years old or greater and initiated on an antiTNF agent at VASDHS between 2010 and 2011. The index date was determined to be the first fill-date of the anti-TNF agent at VASDHS.

Clinical efficacy was categorized as responder, partial responder, and non-responder which were determined from chart notes as defined by the provider. Responders were defined as any documented report of improvement from baseline based on resolution of symptoms and clinical assessment by the provider. Partial responders were defined as any documented report of partial improvement from baseline based on attenuated but continued symptoms and clinical assessment by the provider. Non-responders were defined as any documented report of no improvement from baseline based on continued or worsening of symptoms and clinical assessment by the provider. Two reviewers independently performed the chart reviews (MB and NM) and any disagreements on clinical response were resolved through group discussion.

Primary indication for the anti-TNF agent was determined through the submission of nonformulary (or prior authorization) consults which were reviewed by the VASDHS pharmacy service pharmacoeconomics/formulary group. Anti-TNF agents are listed as non-formulary in the 
VHA; therefore, requests for these agents in VASDHS require a submission of a non-formulary consult. Providers were required to list the primary indication for anti-TNF agent use. If more than one indication was listed, then the primary indication was categorized according to the specialty field of the submitting provider. For example, a rheumatology provider who submitted a non-formulary consult for both arthritis and psoriasis will have the indication categorized for RA.

Primary aim evaluated response at 12 months post-index date. A majority of clinical trails evaluated response at 12 months; therefore, we also followed this convention. Secondary aims evaluated initial response to anti-TNF agents prior to the 12 months post-index date, alternative strategy after failure to respond or development of an adverse drug event to the initial anti-TNF agent, and infection events. Reporting was further stratified into the top three indications: RA, $\mathrm{CD}$, and psoriasis. Infection events included any infection that occurred after the index date up to 12 months post-index date.

This study received appropriate approvals from the UCSD/VASDHS Institutional Review Board and the Research and Development Committee (Protocol \#: H120150).

\section{Statistical analysis:}

Normality testing was performed using Shapiro-Wilk's test for continuous data. Descriptive analyses for continuous data were presented as mean, standard deviation, and median. Discrete data were presented as frequency and percentage. One-way analysis of variance and KruskalWallis tests were performed for continuous data where appropriate. Pearson's chi-squared and Fisher's exact tests were performed for discrete data. 
159 Logistic regression was performed to evaluate the association between anti-TNF agents and 160 response controlling for potential confounders. The outcome variable was transformed into a 161 binary variable in order to perform the logistic regression. Responders and partial responders 162 were collapsed into "Responders." Non-responder and patients who experienced an adverse drug 163 event were categorized as "Non-responders." Model fit was assessed using Hosmer-Lemeshow 164 test. Statistical significance was defined as $\mathrm{P}<0.05$, two-tailed. All analyses were performed using 165 IBM SPSS Statistics for Windows, Version 20.0 (Armonk, NY: IBM Corp). 


\section{Results:}

\section{Baseline}

A total of 92 patients met the inclusion criteria. Table 1 summarizes the demographic variables of the cohort. The average patient was $50(\mathrm{SD}, 16.2)$ years old, male $(\mathrm{N}=77,84 \%)$, non-Hispanic $(\mathrm{N}=78,85 \%)$, and white $(\mathrm{N}=68,74 \%)$. $\mathrm{CD}$ was the most common indication for an anti-TNF agent $(\mathrm{N}=25,27 \%)$ followed by $\mathrm{RA}(\mathrm{N}=22,24 \%)$, psoriasis $(\mathrm{N}=19,21 \%)$, psoriatic arthritis $(\mathrm{N}=13,14 \%)$, other conditions $(\mathrm{N}=8,9 \%)$, and ankylosing spondylitis $(\mathrm{N}=5,5 \%)$. The most common comorbid conditions were hypertension $(\mathrm{N}=39,42 \%)$, dyslipidemia $(\mathrm{N}=36,39 \%)$, gastrointestinal conditions excluding $\mathrm{CD}(\mathrm{N}=24,26 \%)$, cardiovascular disease $(\mathrm{N}=11,12 \%)$, and diabetes $(\mathrm{N}=11,12 \%)$. Several patients were on prednisone $(\mathrm{N}=18,20 \%)$ or methotrexate $(\mathrm{N}=15$, $16 \%)$ at baseline. Less than half of the study patients had previous experience with an anti-TNF agent $(\mathrm{N}=42,46 \%)$, most commonly adalimumab $(\mathrm{N}=22)$ followed by etanercept $(\mathrm{N}=11)$ and infliximab $(\mathrm{N}=9)$.

A majority of patients were started on adalimumab $(\mathrm{N}=37)$ and etanercept $(\mathrm{N}=38)$ followed by infliximab ( $\mathrm{N}=17)$ between 2010 and 2011 at VASDHS (Table 2). There were no differences in age $(\mathrm{P}=0.141)$, gender $(\mathrm{P}=0.480)$, ethnicity $(\mathrm{P}=0.132)$, and race $(\mathrm{P}=0.726)$ between the three antiTNF agents. No difference in primary diagnosis for anti-TNF agent use was reported with RA $(\mathrm{P}=0.119)$, psoriatic arthritis $(\mathrm{P}=0.167)$, ankylosing spondylitis $(\mathrm{P}=0.474)$, and other conditions $(\mathrm{P}=0.157)$ between the three anti-TNF agents. Infliximab and adalimumab were often used in $\mathrm{CD}$ compared to etanercept $(\mathrm{P}<0.0001)$. Conversely, a majority of patients received adalimumab to treat psoriasis relative to the other agents $(\mathrm{P}<0.0001)$. There were no statistically significant difference in comorbidities between the three anti-TNF agents except for hypertension $(\mathrm{P}=0.023)$, other gastrointestinal conditions other than $\mathrm{CD}(\mathrm{P}=0.016)$, and hypothyroidism $(\mathrm{P}=0.020)$. $\mathrm{A}$ 
majority of patients had tuberculosis screening $(\mathrm{N}=83,90 \%)$ and hepatitis $\mathrm{B}$ screening $(\mathrm{N}=73$, 79\%) performed at baseline.

At baseline, methotrexate was only reported by patients who started on etanercept $(\mathrm{N}=8)$ and adalimumab ( $\mathrm{N}=7)$. A small number of prednisone prescriptions were written at baseline during initiation of etanercept $(\mathrm{N}=6)$, adalimumab $(\mathrm{N}=8)$, and infliximab $(\mathrm{N}=4)$. Among patients who started on etanercept at the VASDHS, six had previous experience with it. Similarly, among patients who were initiated on adalimumab and infliximab at VASDHS, eleven and two patients had a previous history with those agents, respectively.

\section{Clinical Response}

The average time to first follow-up visit was 86 (SD, 120) days. At the initial follow-up, 73 (83\%) patients responded (responder and partial responder) to therapy (Table 3). At 12 months follow-up, a majority of patients responded (responder and partial responder) to therapy ( $\mathrm{N}=65$, 71\%). After 12 months of follow-up, there were 15 unique cases (16\%) of infections that did not require hospital admissions, and three adverse drug events were reported which resulted in discontinuation of anti-TNF agent therapy. Two of the drug events that resulted in discontinuation were infection-related (abscess and surgical wound); the other was for myelosplastic syndrome.

At 12 months follow up, there was no significant differences in responses between anti-TNF agents $(\mathrm{P}=0.904)$. In patients initiated on etanercept, $18(49 \%)$ were responders, $6(16 \%)$ were partial responders, $6(16 \%)$ were non-responders, and $2(5 \%)$ had an adverse drug event (myelospastic syndrome and surgical wound infection) at 12 months (Figure 1). In patients initiated on adalimumab, $23(61 \%)$ were responders, 8 (21\%) were partial responders, $4(11 \%)$ were non-responders, and $1(3 \%)$ had an adverse drug event (abscess) at 12 months. In patients 
211 initiated on infliximab, $8(47 \%)$ were responders, $2(12 \%)$ were partial responders, $2(12 \%)$ were

212 non-responders, and 0 had an adverse drug event at 12 months. There were missing data for 5, 2

213 and 5 patients in the etanercept, adalimumab, and infliximab groups, respectively. These missing

214 data were considered missing completely at random; therefore complete-case analysis was

215 appropriate.(Little and Rubin, 2002)

216 Responders were stratified by RA, CD, and psoriasis for each anti-TNF agent (Figure 2). In RA, $21791 \%$ of patients receiving adalimumab were responders compared to $78 \%$ with etanercept. In CD, $21889 \%$ of patients receiving infliximab were responders compared to $73 \%$ with adalimumab. In 219 psoriasis, $100 \%$ of patients receiving adalimumab were responders compared to $64 \%$ receiving 220 etanercept.

221 Infections were reported for $5(14 \%), 10(26 \%)$, and $0(0 \%)$ patients in the etanercept, 222 adalimumab, and infliximab groups, respectively. This difference in infection rates between all 223 three anti-TNF agents was statistically significant $(\mathrm{P}=0.043)$.

224 Unadjusted odds of being a responder were 0.60 (95\% CI: $0.11,3.34)$ and 1.24 (95\% CI: 0.21 , 225 7.41) for patients initiated on etanercept and adalimumab relative to infliximab, respectively 226 (Table 4). Controlling for age, gender, and previous history of anti-TNF agent use, the odds of 227 being a responder was $0.91(95 \%$ CI: $0.13,6.23)$ and $1.85(95 \%$ CI: $0.26,13.10)$ for patients 228 initiated on etanercept and adalimumab relative to infliximab, respectively. 


\section{Discussion:}

At VASDHS, patients initiated on an anti-TNF agent had a high proportion classified as responder (responder and partial responder) after 12 months of therapy. Reports from several clinical studies support this observation. Weinblatt, et al. (2003) reported that $67 \%$ of patients randomized into adalimumab $40 \mathrm{mg}$ every 2 weeks plus methotrexate for RA achieved American College of Rheumatology 20\% (ACR20) at 24-week follow-up (Weinblatt et al., 2003). Kameda, et al. (2010) reported that $90 \%$ of patients randomized into etanercept $25 \mathrm{mg}$ twice weekly for RA achieved ACR20 at 24-week follow-up (Kameda et al., 2010). Colombel, et al. (2010) investigated the efficacy of infliximab $5 \mathrm{mg}$ per $\mathrm{kg}$ plus azathioprine in CD over a 30 week period and reported a remission rate of 57\% (Colombel et al., 2010). Sandborn, et al. (2007) evaluated the long-term effectiveness of adalimumab $40 \mathrm{mg}$ weekly and $40 \mathrm{mg}$ every other week over 56 weeks in moderate-to-severe CD (Sandborn et al., 2007b). Remission was maintained in $83 \%$ and $79 \%$ of patients taking adalimumab $40 \mathrm{mg}$ weekly and adalimumab $40 \mathrm{mg}$ every other week, respectively (Sandborn et al., 2007b).

$\mathrm{Ng}$, et al. (2013) performed a retrospective cohort study of biologic utilization for RA in the VA population from 1999 to 2009 (Ng et al., 2013). Biologics used as the first DMARD increased from $3 \%$ in $1999-2001$ to $6.7 \%$ in $2006-2007(\mathrm{P}<0.001)(\mathrm{Ng}$ et al., 2013). However, the proportion of patients who had a biologic dispensed for RA was stable over the years ranging from $18.6 \%$ to $26.7 \%$ ( $\mathrm{Ng}$ et al., 2013). We reported that $17 \%$ of patients who initiated etanercept previously had been on an anti-TNF agent; and $90 \%$ of patients who were initiated on adalimumab at VASDHS had previous experience with an anti-TNF agent. We adjusted for this in the logistic regression model and found that there was no significant confounding with previous history of anti-TNF agent use on the exposure-outcome relationship. A concern with previous anti-TNF agent use is confounding by indication where patients are inherently different due to 
severity of their disease which results in residual confounding (Salas et al., 1999). Future studies will need to address whether previous history of anti-TNF therapy have an impact on outcomes at 12 months follow up.

Utilization of anti-TNF agents in the CD veteran population has not been previously performed. However, an evaluation of hospitalization associated with $\mathrm{CD}$ in veterans was performed by Sonnenberg and colleagues (Sonnenberg et al., 2009). From 1975 to 2006, the total number of hospitalizations associated with CD among veterans was 54,271 with the highest proportion in the 54-64 year age group ( $\mathrm{N}=22,551)$ (Sonnenberg et al., 2009). The incidence rate for hospitalization was 11.63 per 1 million population.(Sonnenberg et al., 2009) Among veteran population, $\mathrm{CD}$ is a moderately severe chronic disease that has modest resource consumption. However, the use of anti-TNF agents increases the overall direct costs associated with CD. Our results provide real world effectiveness of anti-TNF agents on CD in the veteran population; however, we did not evaluate whether the strategy was based on a top-down or step-up approach (D’Haens, 2009; Hanauer, 2003; Lin et al., 2010). Debate continues on whether a top-down approach is more effective and efficient relative to a step-up approach for CD treatment and management (D’Haens, 2009; Hanauer, 2003; Lin et al., 2010).

We reported on anti-TNF agent use across a wide spectrum of different indications. We also presented the effectiveness of anti-TNF agents for the top three indications: RA, CD, and psoriasis, but small sample size prevented us from performing additional statistical tests. The high proportion of patients who were responders for $\mathrm{RA}, \mathrm{CD}$, and psoriasis provide some support for the effectiveness of anti-TNF agents at 12 months which parallels the results of other studies (Breedveld et al., 2006; Colombel et al., 2010, 2007; Kameda et al., 2010; Sandborn et al., 2007b; Weinblatt et al., 2003, 1999). Justification for using anti-TNF agents for these three indications 
will require a more robust analysis with a larger veteran population along with cost-effectiveness analyses.

Developing infection is a risk associated with using anti-TNF agents. Lane, et al. reported that VA patients using anti-TNF agents for RA from 1998 to 2005 were at risk of being hospitalized for an infection [Hazard Ratio $(H R)=1.24 ; 95 \%$ CI; 1.02, 1.50] (Lane et al., 2011). Ford and Peyrin-

Biroulet (2013) reported that patients using anti-TNF agents for CD had higher risk of developing an opportunistic infection compared to placebo [Relative Risk $(\mathrm{RR})=2.05 ; 95 \% \mathrm{CI}: 1.10,3.85$ ]

(Ford and Peyrin-Biroulet, 2013). The risk of developing Mycobacterium tuberculosis was higher but not significant in patients receiving anti-TNF agents compared to placebo $(\mathrm{RR}=2.52 ; 95 \% \mathrm{CI}$ : 0.62, 10.21) (Ford and Peyrin-Biroulet, 2013). We reported that patients on etanercept and adalimumab developed infections; however, these did not require hospitalizations and were treated with oral antibiotics in the outpatient setting. Furthermore, two infection-related adverse events resulted in discontinuation of the anti-TNF agents. Lane, et al. (2011) reported that patients receiving infliximab for RA had a higher hazard of hospitalized infections relative to etanercept $(\mathrm{HR}=1.51 ; 95 \% \mathrm{CI}: 1.14,2.00)$; and patients receiving adalimumab had a lower but non-significant hazard of hospitalized infections relative to etanercept $(\mathrm{HR}=0.95 ; 95 \% \mathrm{CI}: 0.68$, 1.33) (Lane et al., 2011). In our study, we reported that patients in the adalimumab group had more infections compared to the etanercept group; and no infections were reported in the infliximab group. This conflict may be due to the small sample size which potentially introduces type II error. Furthermore, Lane, et al (Lane et al., 2011) focused on hospitalized infections in RA while our report described non-hospitalized infection events for all anti-TNF agent indications. In our study, stratifying by RA, we observed that 2 out of 7 patients receiving adalimumab developed an infection; however, infections were not observed in the other groups for RA (data not presented). Future studies will need to incorporate a larger sample size in order to capture any 
infection events stratified by disease.

301

Our study has limitations that are inherent to observational studies and studies involving chart reviews. This was a retrospective study that used manual chart reviews to abstract the relevant data. Consequently, there may be some validity issues with how responders and non-responders were determined. Published studies use standardized and validated criteria (ACR, DAS, and CDAI) to generate an objective score for a disease (e.g., RA and CD). However, in practice, these criteria may not always be used or may be impractical. As a result, manual chart reviews are often necessary to determine response to therapy. Previous studies have demonstrated that manual chart reviews may be more sensitive in identifying cases of RA compared to using electronic medical record or ICD-9 coding (Liao et al., 2010; Love et al., 2011; Tinoco et al., 2011). However, interpretation of the meaning and intention of the chart notes require careful attention to the signs and symptoms of disease and improvement in patient functionality. Misclassification may pose a potential source of internal validity; therefore, we took precautions and used two independent chart reviewers to mitigate this problem. This example highlights an important limitation with using chart review in determining response. Due to a lack of objective reporting, evaluation of success with anti-TNF agents would be reduced to evaluation based on a case definition of response. We acknowledge that misclassification is an important bias that cannot be truly ruled out. Ideally, an objective measurement should be recorded in the patient's chart; however, this has not been a requirement for reimbursement or continuation of anti-TNF agents. Future policy development may consider this as a need in order to accurately report response in patients receiving these costly agents.

321 We focused on a single site, which may not be generalizable to other VA institutions. Although 322 each VA medical center abides by the VHA National Formulary, differences in practice may exist 
at individual sites. A lack of a VA national criteria or guideline for anti-TNF agents in RA and CD has led some sites to develop their own local criteria for use. These criteria may differ resulting in a variety of methods for providers to get access to anti-TNF agents for prescribing. In addition, our study focused on a single VA medical center population which limits generalizability to the general veteran population. Future studies will need to incorporate the entire VA population using anti-TNF agents to confirm our findings.

This study had missing data, which is a concern, especially if the missing data is informative. We chose to assume that the missing data was not informative. This does not rule out the possibility that bias exists. Caution should be applied when extrapolating what potential effect these missing data would have on the overall conclusion of this observational study.

Patients who were categorized as non-responders could have been switched to another anti-TNF agent, continued on the anti-TNF agent, or discontinued altogether. It was not possible to establish the average time that these patients were on an anti-TNF agent due to these issues. We reported that the average time to follow up was 86 days, which may not reflect the average follow up in the community. Further observational studies should evaluate the average time to follow up with anti-TNF agents in order to establish the optimal time to measure efficacy and safety.

We reported that several patients were on DMARDs at baseline. However, due to the small sample size, we were unable to evaluate whether they were meaningful differences with this population in terms of effectiveness and safety. Future studies should investigate this population and whether increased effectiveness or worsening side effect profile is reported.

343 Finally, patients at the VA may have dual care with non-VA medical centers and providers. These 
344 patients may have experienced changes in their therapy and received treatment for infections that 345 were not captured with the VA electronic records. Clinical trials have reported the proportion of 346 patients with infections ranging from 5.7\% (Emery et al., 2009) to 46\% (Colombel et al., 2010).

347 To complicate matters, patient healthcare benefits may not be restricted to the VA resulting in 348 patients "shopping” for different providers. This may lead to vital information about the patient's 349 disease and status that are not shared with the VA (Nayar et al., 2013a, 2013b; Weeks et al., 350 2002). As a result, there may be some underreporting of infection events with our analysis.

351 We did not observe golimumab and certolizumab pegol utilization at VASDHS between 2010 and 352 2011, despite their availability. We speculate that this was due to their novelty, lack of provider 353 experience, and availability of alternative biologic agents (e.g., IL-6 inhibitors and integrin 354 inhibitors). Although these other anti-TNF agents were not used at VASDHS, it is possible that 355 they may have been utilized at different VA facilities. Future studies will need to expand this 356 investigation to include more VA facilities in order to capture golimumab and certolizumab pegol 357 utilization. 
Conclusion:

359 A majority of patients who were initiated with an anti-TNF agent in the VA were categorized as 360 responders at 12 months follow-up. This was observed for RA and CD indications. Infections

361 were only observed in etanercept and adalimumab patients; however, low sample size in the 362 infliximab subgroup may introduce type II error. Future studies will need to investigate the entire 363 VA population using anti-TNF agents to determine if response is consistent with those reported at 364 VASDHS. 


\section{References:}

Agarwal, S.K., 2011a. Core management principles in rheumatoid arthritis to help guide managed care professionals. J. Manag. Care Pharm. JMCP 17, S03-08.

Agarwal, S.K., 2011b. Biologic agents in rheumatoid arthritis: an update for managed care professionals. J. Manag. Care Pharm. JMCP 17, S14-18.

Ancuța, C., Ancuța, E., Miu, S., Iordache, C., Belibou, C., Chirieac, R., 2009. Adalimumab therapy in patients with active rheumatoid arthritis. Rev. Medico-Chir. Soc. Medici Şi Nat. Din Iaşi 113, 710-715.

Bathon, J.M., Martin, R.W., Fleischmann, R.M., Tesser, J.R., Schiff, M.H., Keystone, E.C., Genovese, M.C., Wasko, M.C., Moreland, L.W., Weaver, A.L., Markenson, J., Finck, B.K., 2000. A comparison of etanercept and methotrexate in patients with early rheumatoid arthritis. N. Engl. J. Med. 343, 1586-1593.

Baumgart, D.C., Sandborn, W.J., 2012. Crohn's disease. Lancet 380, 1590-1605.

Bodger, K., 2002. Cost of illness of Crohn's disease. PharmacoEconomics 20, 639-652.

Breedveld, F.C., Weisman, M.H., Kavanaugh, A.F., Cohen, S.B., Pavelka, K., van Vollenhoven, R., Sharp, J., Perez, J.L., Spencer-Green, G.T., 2006. The PREMIER study: A multicenter, randomized, double-blind clinical trial of combination therapy with adalimumab plus methotrexate versus methotrexate alone or adalimumab alone in patients with early, aggressive rheumatoid arthritis who had not had previous methotrexate treatment. Arthritis Rheum. 54, 26-37.

Choy, E., McKenna, F., Vencovsky, J., Valente, R., Goel, N., Vanlunen, B., Davies, O., Stahl, H.D., Alten, R., 2012. Certolizumab pegol plus MTX administered every 4 weeks is effective in patients with RA who are partial responders to MTX. Rheumatol. Oxf. Engl. 51, 1226-1234.

Colombel, J.-F., Sandborn, W.J., Reinisch, W., Mantzaris, G.J., Kornbluth, A., Rachmilewitz, D., Lichtiger, S., D’Haens, G., Diamond, R.H., Broussard, D.L., Tang, K.L., van der Woude, C.J., Rutgeerts, P., 2010. Infliximab, azathioprine, or combination therapy for Crohn's disease. N. Engl. J. Med. 362, 1383-1395.

Colombel, J.-F., Sandborn, W.J., Rutgeerts, P., Enns, R., Hanauer, S.B., Panaccione, R., Schreiber, S., Byczkowski, D., Li, J., Kent, J.D., Pollack, P.F., 2007. Adalimumab for maintenance of clinical response and remission in patients with Crohn's disease: the CHARM trial. Gastroenterology 132, 52-65.

D'Haens, G.R., 2009. Top-down therapy for Crohn's disease: rationale and evidence. Acta Clin. Belg. 64, 540-546.

Emery, P., Breedveld, F., van der Heijde, D., Ferraccioli, G., Dougados, M., Robertson, D., Pedersen, R., Koenig, A.S., Freundlich, B., Combination of Methotrexate and Etanercept in Early Rheumatoid Arthritis Trial Group, 2010. Two-year clinical and radiographic results with combination etanercept-methotrexate therapy versus monotherapy in early rheumatoid arthritis: a two-year, double-blind, randomized study. Arthritis Rheum. 62, 674-682.

Emery, P., Fleischmann, R.M., Moreland, L.W., Hsia, E.C., Strusberg, I., Durez, P., Nash, P., Amante, E.J.B., Churchill, M., Park, W., Pons-Estel, B.A., Doyle, M.K., Visvanathan, S., $\mathrm{Xu}$, W., Rahman, M.U., 2009. Golimumab, a human anti-tumor necrosis factor alpha monoclonal antibody, injected subcutaneously every four weeks in methotrexate-naive patients with active rheumatoid arthritis: twenty-four-week results of a phase III, multicenter, randomized, double-blind, placebo-controlled study of golimumab before methotrexate as first-line therapy for early-onset rheumatoid arthritis. Arthritis Rheum. 60, 2272-2283. 
FDA Office of the Commissioner, 2008. FDA Approves Cimzia to Treat Crohn's Disease [WWW Document]. URL http://www.fda.gov/NewsEvents/Newsroom/PressAnnouncements/2008/ucm116882.htm (accessed 6.23.13).

Feagan, B.G., Coteur, G., Tan, S., Keininger, D.L., Schreiber, S., 2009. Clinically meaningful improvement in health-related quality of life in a randomized controlled trial of certolizumab pegol maintenance therapy for Crohn's disease. Am. J. Gastroenterol. 104, 1976-1983.

Ford, A.C., Peyrin-Biroulet, L., 2013. Opportunistic Infections With Anti-Tumor Necrosis Factor$\alpha$ Therapy in Inflammatory Bowel Disease: Meta-Analysis of Randomized Controlled Trials. Am. J. Gastroenterol.

Ford, A.C., Sandborn, W.J., Khan, K.J., Hanauer, S.B., Talley, N.J., Moayyedi, P., 2011. Efficacy of biological therapies in inflammatory bowel disease: systematic review and metaanalysis. Am. J. Gastroenterol. 106, 644-659, quiz 660.

Gabriel, S.E., Michaud, K., 2009. Epidemiological studies in incidence, prevalence, mortality, and comorbidity of the rheumatic diseases. Arthritis Res. Ther. 11, 229.

Hanauer, S.B., 2003. Crohn's disease: step up or top down therapy. Best Pract. Res. Clin. Gastroenterol. 17, 131-137.

Hanauer, S.B., Sandborn, W.J., Rutgeerts, P., Fedorak, R.N., Lukas, M., MacIntosh, D., Panaccione, R., Wolf, D., Pollack, P., 2006. Human anti-tumor necrosis factor monoclonal antibody (adalimumab) in Crohn's disease: the CLASSIC-I trial. Gastroenterology 130, 323-333; quiz 591.

Helmick, C.G., Felson, D.T., Lawrence, R.C., Gabriel, S., Hirsch, R., Kwoh, C.K., Liang, M.H., Kremers, H.M., Mayes, M.D., Merkel, P.A., Pillemer, S.R., Reveille, J.D., Stone, J.H., National Arthritis Data Workgroup, 2008. Estimates of the prevalence of arthritis and other rheumatic conditions in the United States. Part I. Arthritis Rheum. 58, 15-25.

Hou, J.K., Kramer, J.R., Richardson, P., Mei, M., El-Serag, H.B., 2013. The incidence and prevalence of inflammatory bowel disease among U.S. veterans: a national cohort study. Inflamm. Bowel Dis. 19, 1059-1064.

Kameda, H., Ueki, Y., Saito, K., Nagaoka, S., Hidaka, T., Atsumi, T., Tsukano, M., Kasama, T., Shiozawa, S., Tanaka, Y., Takeuchi, T., Japan Biological Agent Study Integrated Consortium, 2010. Etanercept (ETN) with methotrexate (MTX) is better than ETN monotherapy in patients with active rheumatoid arthritis despite MTX therapy: a randomized trial. Mod. Rheumatol. Jpn. Rheum. Assoc. 20, 531-538.

Kappelman, M.D., Rifas-Shiman, S.L., Porter, C.Q., Ollendorf, D.A., Sandler, R.S., Galanko, J.A., Finkelstein, J.A., 2008. Direct health care costs of Crohn's disease and ulcerative colitis in US children and adults. Gastroenterology 135, 1907-1913.

Keystone, E., Heijde, D. van der, Mason, D., Jr, Landewé, R., Vollenhoven, R.V., Combe, B., Emery, P., Strand, V., Mease, P., Desai, C., Pavelka, K., 2008. Certolizumab pegol plus methotrexate is significantly more effective than placebo plus methotrexate in active rheumatoid arthritis: findings of a fifty-two-week, phase III, multicenter, randomized, double-blind, placebo-controlled, parallel-group study. Arthritis Rheum. 58, 3319-3329.

Keystone, E.C., Genovese, M.C., Klareskog, L., Hsia, E.C., Hall, S.T., Miranda, P.C., Pazdur, J., Bae, S.-C., Palmer, W., Zrubek, J., Wiekowski, M., Visvanathan, S., Wu, Z., Rahman, M.U., GO-FORWARD Study, 2009. Golimumab, a human antibody to tumour necrosis factor \{alpha\} given by monthly subcutaneous injections, in active rheumatoid arthritis despite methotrexate therapy: the GO-FORWARD Study. Ann. Rheum. Dis. 68, 789-796. Keystone, E.C., Kavanaugh, A.F., Sharp, J.T., Tannenbaum, H., Hua, Y., Teoh, L.S., Fischkoff, S.A., Chartash, E.K., 2004. Radiographic, clinical, and functional outcomes of treatment 
with adalimumab (a human anti-tumor necrosis factor monoclonal antibody) in patients with active rheumatoid arthritis receiving concomitant methotrexate therapy: a randomized, placebo-controlled, 52-week trial. Arthritis Rheum. 50, 1400-1411.

Klareskog, L., van der Heijde, D., de Jager, J.P., Gough, A., Kalden, J., Malaise, M., Martín Mola, E., Pavelka, K., Sany, J., Settas, L., Wajdula, J., Pedersen, R., Fatenejad, S., Sanda, M., TEMPO (Trial of Etanercept and Methotrexate with Radiographic Patient Outcomes) study investigators, 2004. Therapeutic effect of the combination of etanercept and methotrexate compared with each treatment alone in patients with rheumatoid arthritis: double-blind randomised controlled trial. Lancet 363, 675-681.

Lane, M.A., McDonald, J.R., Zeringue, A.L., Caplan, L., Curtis, J.R., Ranganathan, P., Eisen, S.A., 2011. TNF- $\alpha$ antagonist use and risk of hospitalization for infection in a national cohort of veterans with rheumatoid arthritis. Medicine (Baltimore) 90, 139-145.

Lee, T.A., Shields, A.E., Vogeli, C., Gibson, T.B., Woong-Sohn, M., Marder, W.D., Blumenthal, D., Weiss, K.B., 2007. Mortality rate in veterans with multiple chronic conditions. J. Gen. Intern. Med. 22 Suppl 3, 403-407.

Liao, K.P., Cai, T., Gainer, V., Goryachev, S., Zeng-treitler, Q., Raychaudhuri, S., Szolovits, P., Churchill, S., Murphy, S., Kohane, I., Karlson, E.W., Plenge, R.M., 2010. Electronic medical records for discovery research in rheumatoid arthritis. Arthritis Care Res. 62, $1120-1127$.

Lichtenstein, G.R., Hanauer, S.B., Sandborn, W.J., Practice Parameters Committee of American College of Gastroenterology, 2009. Management of Crohn's disease in adults. Am. J. Gastroenterol. 104, 465-483; quiz 464, 484.

Lin, M.V., Blonski, W., Lichtenstein, G.R., 2010. What is the optimal therapy for Crohn's disease: step-up or top-down? Expert Rev. Gastroenterol. Hepatol. 4, 167-180.

Little, R.J.A., Rubin, D.B., 2002. Statistical Analysis with Missing Data, Second Edition. ed. John Wiley \& Sons, Inc., Hoboken, NJ.

Loftus, C.G., Loftus, E.V., Jr, Harmsen, W.S., Zinsmeister, A.R., Tremaine, W.J., Melton, L.J., 3rd, Sandborn, W.J., 2007. Update on the incidence and prevalence of Crohn's disease and ulcerative colitis in Olmsted County, Minnesota, 1940-2000. Inflamm. Bowel Dis. 13, 254-261.

Loftus, E.V., Jr, Schoenfeld, P., Sandborn, W.J., 2002. The epidemiology and natural history of Crohn's disease in population-based patient cohorts from North America: a systematic review. Aliment. Pharmacol. Ther. 16, 51-60.

Loomes, D.E., Teshima, C., Jacobs, P., Fedorak, R.N., 2011. Health care resource use and costs in Crohn's disease before and after infliximab therapy. Can. J. Gastroenterol. J. Can. Gastroenterol. 25, 497-502.

Louis, E., Löfberg, R., Reinisch, W., Camez, A., Yang, M., Pollack, P.F., Chen, N., Chao, J., Mulani, P.M., 2013. Adalimumab improves patient-reported outcomes and reduces indirect costs in patients with moderate to severe Crohn's disease: results from the CARE trial. J. Crohns Colitis 7, 34-43.

Love, T.J., Cai, T., Karlson, E.W., 2011. Validation of psoriatic arthritis diagnoses in electronic medical records using natural language processing. Semin. Arthritis Rheum. 40, 413-420.

Lundkvist, J., Kastäng, F., Kobelt, G., 2008. The burden of rheumatoid arthritis and access to treatment: health burden and costs. Eur. J. Health Econ. HEPAC Health Econ. Prev. Care 8 Suppl 2, S49-60.

Maini, R., St Clair, E.W., Breedveld, F., Furst, D., Kalden, J., Weisman, M., Smolen, J., Emery, P., Harriman, G., Feldmann, M., Lipsky, P., 1999. Infliximab (chimeric anti-tumour necrosis factor alpha monoclonal antibody) versus placebo in rheumatoid arthritis patients 
receiving concomitant methotrexate: a randomised phase III trial. ATTRACT Study Group. Lancet 354, 1932-1939.

Mayberry, J.F., Lobo, A., Ford, A.C., Thomas, A., 2013. NICE clinical guideline (CG152): the management of Crohn's disease in adults, children and young people. Aliment. Pharmacol. Ther. 37, 195-203.

Moreland, L.W., Schiff, M.H., Baumgartner, S.W., Tindall, E.A., Fleischmann, R.M., Bulpitt, K.J., Weaver, A.L., Keystone, E.C., Furst, D.E., Mease, P.J., Ruderman, E.M., Horwitz, D.A., Arkfeld, D.G., Garrison, L., Burge, D.J., Blosch, C.M., Lange, M.L., McDonnell, N.D., Weinblatt, M.E., 1999. Etanercept therapy in rheumatoid arthritis. A randomized, controlled trial. Ann. Intern. Med. 130, 478-486.

Nayar, P., Apenteng, B., Yu, F., Woodbridge, P., Fetrick, A., 2013a. Rural veterans' perspectives of dual care. J. Community Health 38, 70-77.

Nayar, P., Nguyen, A.T., Ojha, D., Schmid, K.K., Apenteng, B., Woodbridge, P., 2013 b. Transitions in dual care for veterans: non-federal physician perspectives. J. Community Health 38, 225-237.

Ng, B., Chu, A., Khan, M.M., 2013. A retrospective cohort study: 10-year trend of diseasemodifying antirheumatic drugs and biological agents use in patients with rheumatoid arthritis at Veteran Affairs Medical Centers. BMJ Open 3.

NIDDK National Digestive Diseases Information Clearinghouse, n.d. Crohn's Disease [WWW Document]. URL http://www.digestive.niddk.nih.gov/ddiseases/pubs/crohns/index.aspx\#treatment (accessed 6.23.13).

Nixon, R.M., Bansback, N., Brennan, A., 2007. Using mixed treatment comparisons and metaregression to perform indirect comparisons to estimate the efficacy of biologic treatments in rheumatoid arthritis. Stat. Med. 26, 1237-1254.

Ordás, I., Feagan, B.G., Sandborn, W.J., 2011. Early use of immunosuppressives or TNF antagonists for the treatment of Crohn's disease: time for a change. Gut 60, 1754-1763.

Salas, M., Hofman, A., Stricker, B.H., 1999. Confounding by indication: an example of variation in the use of epidemiologic terminology. Am. J. Epidemiol. 149, 981-983.

Sandborn, W.J., Feagan, B.G., Stoinov, S., Honiball, P.J., Rutgeerts, P., Mason, D., Bloomfield, R., Schreiber, S., 2007a. Certolizumab pegol for the treatment of Crohn's disease. N. Engl. J. Med. 357, 228-238.

Sandborn, W.J., Hanauer, S.B., Rutgeerts, P., Fedorak, R.N., Lukas, M., MacIntosh, D.G., Panaccione, R., Wolf, D., Kent, J.D., Bittle, B., Li, J., Pollack, P.F., 2007b. Adalimumab for maintenance treatment of Crohn's disease: results of the CLASSIC II trial. Gut 56, $1232-1239$.

Segal, B., Rhodus, N.L., Patel, K., 2008. Tumor necrosis factor (TNF) inhibitor therapy for rheumatoid arthritis. Oral Surg. Oral Med. Oral Pathol. Oral Radiol. Endod. 106, 778787.

Singh, J.A., Cameron, D.R., 2012. Summary of AHRQ's comparative effectiveness review of drug therapy for rheumatoid arthritis (RA) in adults--an update. J. Manag. Care Pharm. JMCP 18, S1-18.

Sonnenberg, A., Richardson, P.A., Abraham, N.S., 2009. Hospitalizations for inflammatory bowel disease among US military veterans 1975-2006. Dig. Dis. Sci. 54, 1740-1745.

St Clair, E.W., van der Heijde, D.M.F.M., Smolen, J.S., Maini, R.N., Bathon, J.M., Emery, P., Keystone, E., Schiff, M., Kalden, J.R., Wang, B., Dewoody, K., Weiss, R., Baker, D., Active-Controlled Study of Patients Receiving Infliximab for the Treatment of Rheumatoid Arthritis of Early Onset Study Group, 2004. Combination of infliximab and 
methotrexate therapy for early rheumatoid arthritis: a randomized, controlled trial. Arthritis Rheum. 50, 3432-3443.

Staples, M.P., March, L., Lassere, M., Reid, C., Buchbinder, R., 2011. Health-related quality of life and continuation rate on first-line anti-tumour necrosis factor therapy among rheumatoid arthritis patients from the Australian Rheumatology Association Database. Rheumatol. Oxf. Engl. 50, 166-175.

Tinoco, A., Evans, R.S., Staes, C.J., Lloyd, J.F., Rothschild, J.M., Haug, P.J., 2011. Comparison of computerized surveillance and manual chart review for adverse events. J. Am. Med. Inform. Assoc. JAMIA 18, 491-497.

Van de Putte, L.B.A., Atkins, C., Malaise, M., Sany, J., Russell, A.S., van Riel, P.L.C.M., Settas, L., Bijlsma, J.W., Todesco, S., Dougados, M., Nash, P., Emery, P., Walter, N., Kaul, M., Fischkoff, S., Kupper, H., 2004. Efficacy and safety of adalimumab as monotherapy in patients with rheumatoid arthritis for whom previous disease modifying antirheumatic drug treatment has failed. Ann. Rheum. Dis. 63, 508-516.

Van der Heijde, D., Klareskog, L., Rodriguez-Valverde, V., Codreanu, C., Bolosiu, H., MeloGomes, J., Tornero-Molina, J., Wajdula, J., Pedersen, R., Fatenejad, S., TEMPO Study Investigators, 2006. Comparison of etanercept and methotrexate, alone and combined, in the treatment of rheumatoid arthritis: two-year clinical and radiographic results from the TEMPO study, a double-blind, randomized trial. Arthritis Rheum. 54, 1063-1074.

Van der Valk, M.E., Mangen, M.-J.J., Leenders, M., Dijkstra, G., van Bodegraven, A.A., Fidder, H.H., de Jong, D.J., Pierik, M., van der Woude, C.J., Romberg-Camps, M.J.L., Clemens, C.H., Jansen, J.M., Mahmmod, N., van de Meeberg, P.C., van der Meulen-de Jong, A.E., Ponsioen, C.Y., Bolwerk, C.J., Vermeijden, J.R., Siersema, P.D., van Oijen, M.G., Oldenburg, B., 2012. Healthcare costs of inflammatory bowel disease have shifted from hospitalisation and surgery towards anti-TNF $\alpha$ therapy: results from the COIN study. Gut.

Weeks, W.B., Yano, E.M., Rubenstein, L.V., 2002. Primary care practice management in rural and urban Veterans Health Administration settings. J. Rural Health Off. J. Am. Rural Health Assoc. Natl. Rural Health Care Assoc. 18, 298-303.

Weinblatt, M.E., Keystone, E.C., Furst, D.E., Moreland, L.W., Weisman, M.H., Birbara, C.A., Teoh, L.A., Fischkoff, S.A., Chartash, E.K., 2003. Adalimumab, a fully human anti-tumor necrosis factor alpha monoclonal antibody, for the treatment of rheumatoid arthritis in patients taking concomitant methotrexate: the ARMADA trial. Arthritis Rheum. 48, 3545.

Weinblatt, M.E., Kremer, J.M., Bankhurst, A.D., Bulpitt, K.J., Fleischmann, R.M., Fox, R.I., Jackson, C.G., Lange, M., Burge, D.J., 1999. A trial of etanercept, a recombinant tumor necrosis factor receptor:Fc fusion protein, in patients with rheumatoid arthritis receiving methotrexate. N. Engl. J. Med. 340, 253-259. 


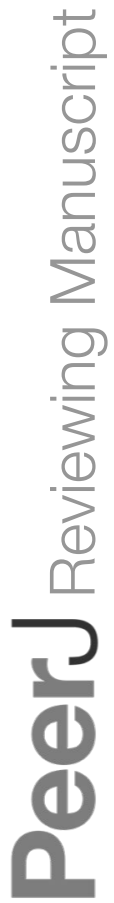

PeerJ reviewing PDF | (v2014:03:1714:1:1:NEW 26 Apr 2014) 


\section{Figure 1}

Outcome with tumor necrosis factor use at 12 months, 2010-2011.

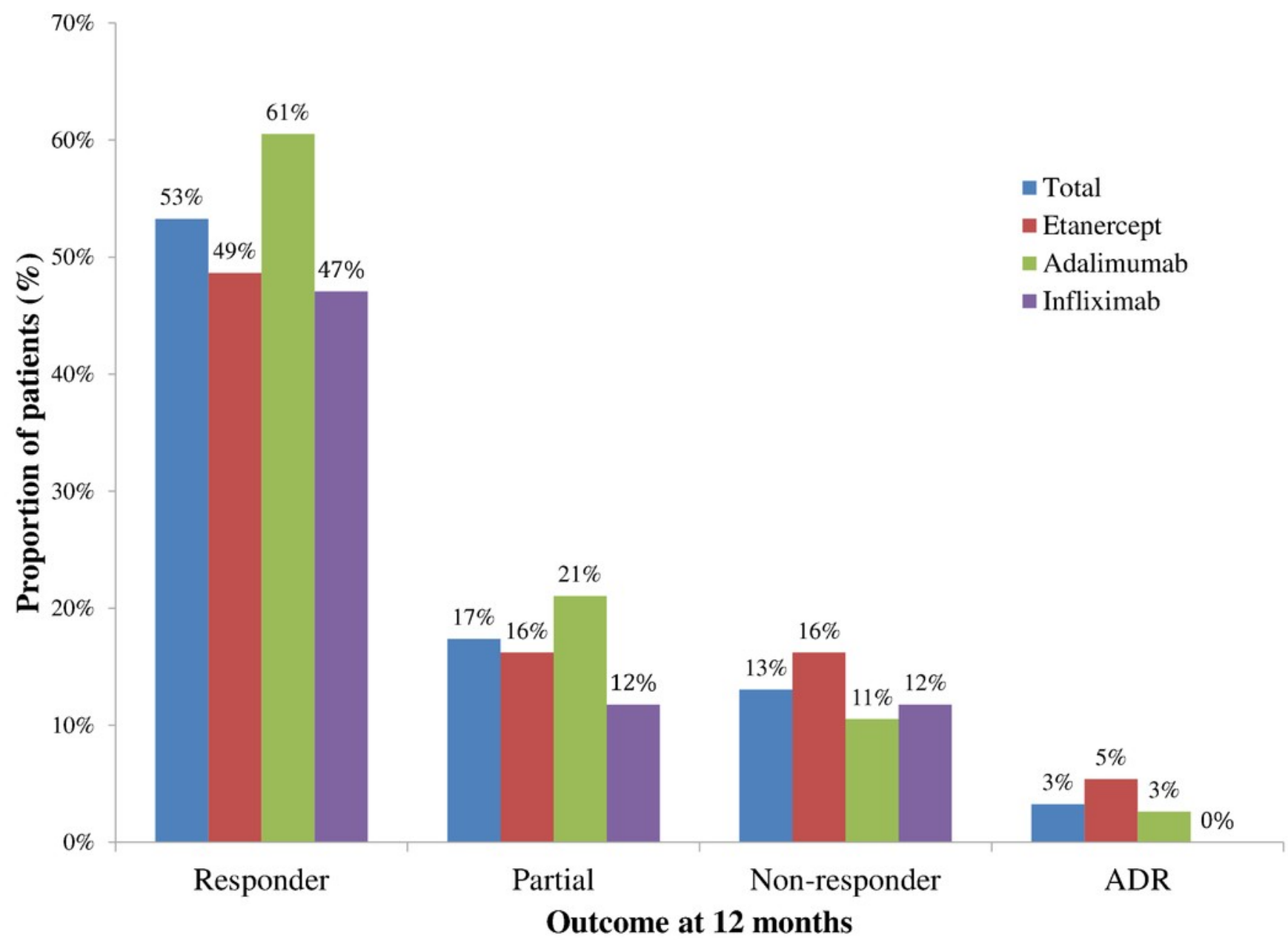




\section{Figure 2}

Outcomes of different anti-TNF agents stratified by the top three disease states, 20102011.

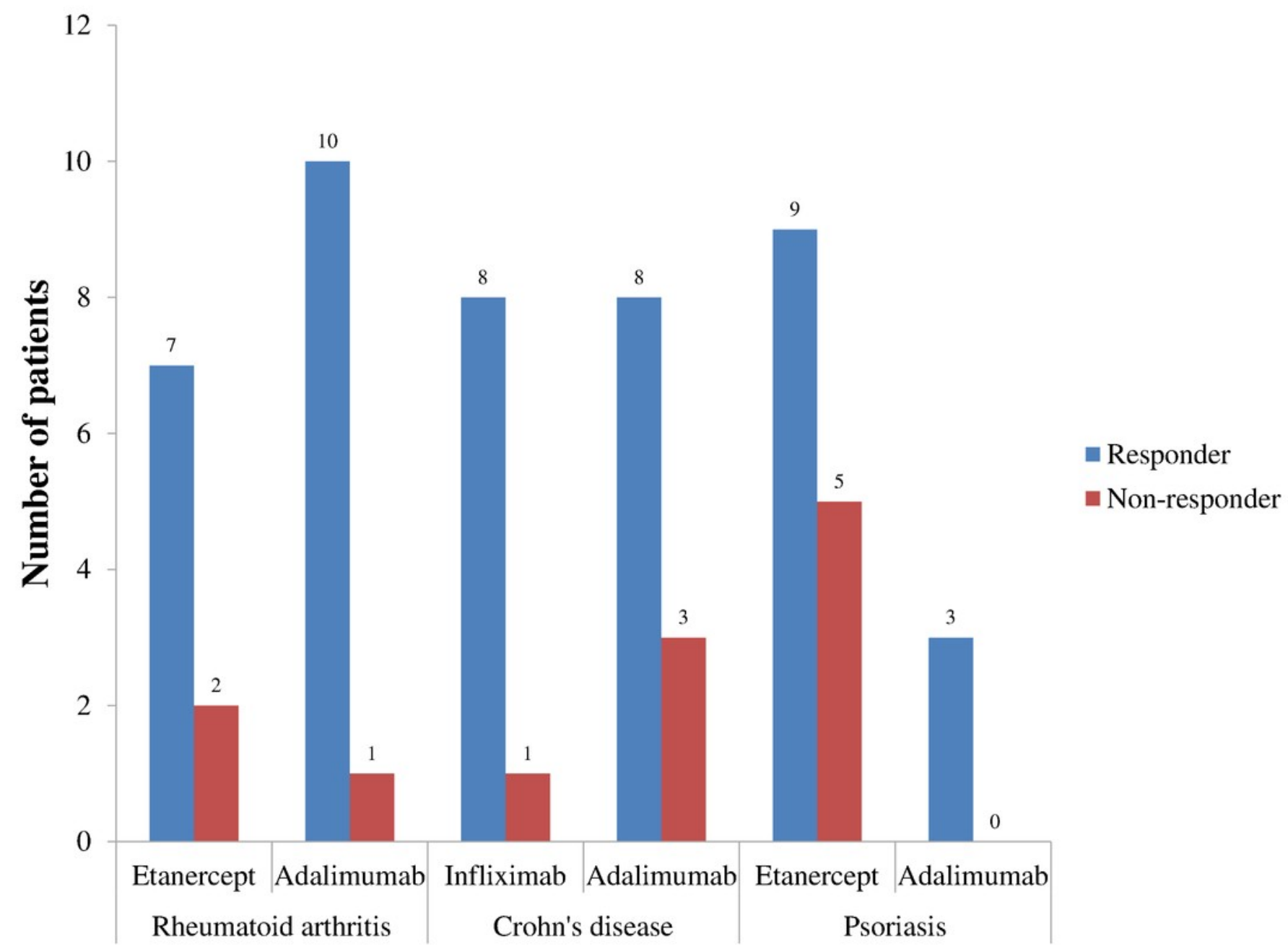




\section{Table 1 (on next page)}

Demographics of entire cohort started in anti-tumor necrosis factor (TNF) agents, 20102011 
$\mathrm{N}$

Variable

Age

BMI

AST

ALT

Ethnicity

Race

$\begin{array}{rcc}\text { Hispanic } & 13 & 14 \% \\ \text { Non-Hispanic } & 78 & 85 \% \\ \text { Unknown } & 1 & 1 \%\end{array}$

Numbe

$r$

Male $\quad 77 \quad 84 \%$

Female $\quad 15 \quad 16 \%$

$\begin{array}{cc}92 & \\ \text { Mean } & \text { SD } \\ 49.97 & 16.23 \\ 28.96 & 5.49 \\ 24.88 & 20.35 \\ 28.13 & 25.71\end{array}$

Percent

$\begin{array}{rcc}\text { White } & 68 & 74 \% \\ \text { Black } & 11 & 12 \% \\ \text { Asian } & 3 & 3 \% \\ \text { Native American/Pacific Islander } & 2 & 2 \% \\ \text { American Indian/Alaskan Native } & 1 & 1 \% \\ \text { Unknown } & 5 & 5 \% \\ \text { Declined } & 2 & 2 \%\end{array}$

Primary Diagnosis

$\begin{array}{rcc}\text { RA } & 23 & 25 \% \\ \text { CD } & 24 & 26 \% \\ \text { Psoriasis } & 19 & 21 \% \\ \text { Psoriatic arthritis } & 13 & 14 \% \\ \text { Other* } & 7 & 8 \% \\ \text { Ankylosing spondylitis } & 5 & 5 \%\end{array}$

Comorbid conditions

$\begin{array}{rcc}\text { Diabetes } & 11 & 12 \% \\ \text { Hypertension } & 39 & 42 \% \\ \text { Arrhythmia } & 3 & 3 \% \\ \text { Heart failure } & 3 & 3 \% \\ \text { Malignancy } & 7 & 8 \% \\ \text { Chronic lung disease } & 5 & 5 \% \\ \text { CVD } & 11 & 12 \% \\ \text { Hepatic disease } & 3 & 3 \% \\ \text { Renal } & 5 & 5 \%\end{array}$




$\begin{array}{rrcc}\text { Gout } & 5 & 5 \% \\ \text { Hepatitis C } & 4 & 4 \% \\ \text { Dyslipidemia } & 36 & 39 \% \\ \text { History of MI } & 2 & 2 \% \\ \text { GI (other than CD) } & 24 & 26 \% \\ \text { Hypothyroidism } & 5 & 5 \% \\ & & \\ \text { MTX } & 15 & 16 \% \\ \text { Prednisone } & 18 & 20 \% \\ \text { SSZ } & 9 & 10 \% \\ & \text { Plaqguenil } & 4 & 4 \%\end{array}$

Previous TNF agent

$\begin{array}{ccc}\text { Yes } & 42 & 46 \% \\ \text { No } & 50 & 54 \%\end{array}$

TNF history

$\begin{array}{rcc}\text { Adalimumab history } & 22 & 24 \% \\ \text { Etanercept history } & 11 & 12 \% \\ \text { Infliximab history } & 9 & 10 \%\end{array}$

TNF history origin

$\begin{array}{rcc}\text { Community provider } & 21 & 23 \% \\ \text { Another VA facility } & 5 & 5 \% \\ \text { Department of Defense } & 4 & 4 \% \\ \begin{array}{r}\text { Healthcare System } \\ \text { Heans Affairs San Diego }\end{array} & 12 & 13 \%\end{array}$

RF result at baseline

$\begin{array}{rrr}\text { Positive } & 11 & 12 \% \\ \text { Negative } & 14 & 15 \%\end{array}$

TB test performed

$\begin{array}{ccc}\text { Yes } & 83 & 90 \% \\ \text { No } & 9 & 10 \%\end{array}$

TB result

$\begin{array}{rcc}\text { Positive } & 3 & 3 \% \\ \text { Negative } & 79 & 86 \%\end{array}$

Hepatitis test performed

$\begin{array}{ccc}\text { Yes } & 73 & 79 \% \\ \text { No } & 19 & 21 \% \\ & 27 & 29 \% \\ & 1 & 1 \% \\ & 7 & 8 \%\end{array}$

*"Other" includes ulcerative colitis $(\mathrm{N}=5)$, uveitis $(\mathrm{N}=1)$, and spondylarthropathy $(\mathrm{N}=1)$. 


\section{Table 2 (on next page)}

Demographics of patients initiated on etanercept, adalimumab, and infliximab, 20102011 
N

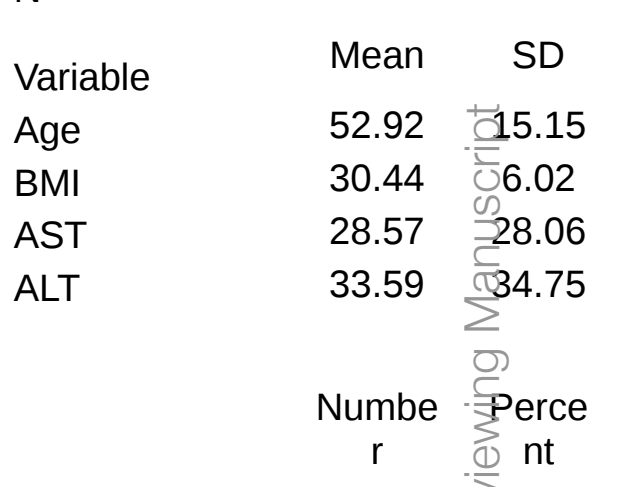

Gender

$\begin{array}{rcc}\text { Male } & 33 & \simeq 89 \% \\ \text { Female } & 4 & 11 \% \\ \text { Ethnicity } & & 11 \% \\ \text { Hispanic } & 4 & 11 \% \\ \text { Non-Hispanic } & 33 & 89 \% \\ \text { Unknown } & 0 & 0 \%\end{array}$

Race

$\begin{array}{rcc}\text { White } & 29 & 78 \% \\ \text { Black } & 5 & 14 \% \\ \text { Asian } & 1 & 3 \% \\ \text { Native } & & \\ \text { American/Pacif } & 1 & 3 \% \\ \text { ic Islander } & & \\ \text { American } & & \\ \text { Indian/Alaskan } & 0 & 0 \% \\ \text { Native } & & \\ \text { Unknown } & 1 & 3 \% \\ \text { Declined } & 0 & 0 \%\end{array}$

Primary

Diagnosis

Rheumatoid $\quad 10 \quad 27 \%$

Inflixima

Adalimumab

38

$\begin{array}{ccc}\begin{array}{c}\text { Media } \\ \mathrm{n}\end{array} & \text { Mean } & \text { SD } \\ 56.0 & 49.47 & 15.97 \\ 30.2 & 28.30 & 4.92 \\ 22.0 & 24.00 & 13.43 \\ 24.0 & 27.92 & 17.59 \\ & & \\ & \text { Numbe } & \text { Perce } \\ & \text { r } & \text { nt }\end{array}$

$30 \quad 79 \%$

$8 \quad 21 \%$

$8 \quad 21 \%$

$30 \quad 79 \%$

$0 \quad 0 \%$

$25 \quad 66 \%$

$5 \quad 13 \%$

$13 \%$

$13 \%$

$13 \%$

$4 \quad 11 \%$

$13 \%$
17

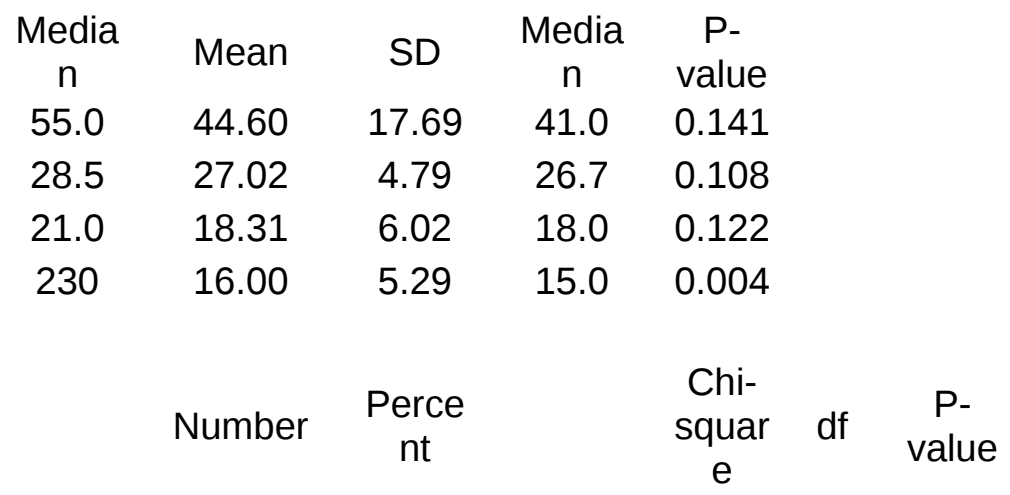

$\begin{array}{lll}1.469 & 2 & 0.480\end{array}$

$\begin{array}{lll}7.069 & 4 & 0.132\end{array}$

$\begin{array}{rr}1 & 6 \% \\ 15 & 88 \%\end{array}$

$16 \%$

$14 \quad 82 \%$

$\begin{array}{lll}8.724 & 1 & 0.726\end{array}$
$16 \%$

$16 \%$

$0 \quad 0 \%$

$0 \quad 0 \%$

$0 \quad 0 \%$

$16 \%$

$12 \quad 32 \%$

$16 \%$

$\begin{array}{lll}4.272 & 2 & 0.119\end{array}$ 


\begin{tabular}{|c|c|c|c|c|c|c|c|c|c|}
\hline arthritis & & & & & & & & & \\
\hline $\begin{array}{l}\text { Crohn's } \\
\text { disease }\end{array}$ & 0 & $0 \%$ & 12 & $32 \%$ & 12 & $71 \%$ & $\begin{array}{c}31.11 \\
3\end{array}$ & 2 & $\begin{array}{l}<0.000 \\
1\end{array}$ \\
\hline $\begin{array}{r}\text { Psoriatic } \\
\text { arthritis }\end{array}$ & 7 & $19 \%$ & 6 & $16 \%$ & 0 & $0 \%$ & 3.583 & 2 & 0.167 \\
\hline $\begin{array}{l}\text { Ankylosing } \\
\text { spondylitis }\end{array}$ & 3 & $8 \%$ & 2 & $5 \%$ & 0 & $0 \%$ & 1.494 & 2 & 0.474 \\
\hline Psoriasis & 16 & $43 \%$ & 3 & $8 \%$ & 0 & $0 \%$ & $\begin{array}{c}19.72 \\
2\end{array}$ & 2 & $\begin{array}{c}<0.000 \\
1\end{array}$ \\
\hline $\begin{array}{l}\text { Other* } \\
\text { Comorbid } \\
\text { conditions }\end{array}$ & 1 & 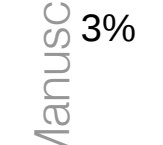 & 3 & $8 \%$ & 3 & $18 \%$ & 3.708 & 2 & 0.157 \\
\hline Diabetes & 7 & $19 \%$ & 4 & $11 \%$ & 0 & $0 \%$ & 4.086 & 2 & 0.130 \\
\hline Hypertension & 21 & $57 \%$ & 15 & $39 \%$ & 3 & $18 \%$ & 7.521 & 2 & 0.023 \\
\hline Arrhythmia & 1 & $3 \%$ & 2 & $5 \%$ & 0 & $0 \%$ & 1.093 & 2 & 0.579 \\
\hline Heart failure & 0 & $0 \%$ & 3 & $8 \%$ & 0 & $0 \%$ & 4.407 & 2 & 0.110 \\
\hline Malignancy & 2 & $\simeq 5 \%$ & 5 & $13 \%$ & 0 & $0 \%$ & 3.32 & 2 & 0.190 \\
\hline $\begin{array}{r}\text { Chronic lung } \\
\text { disease }\end{array}$ & 1 & $3 \%$ & 3 & $8 \%$ & 1 & $6 \%$ & 0.991 & 2 & 0.609 \\
\hline $\begin{array}{r}\text { Cardiovascular } \\
\text { disease }\end{array}$ & 5 & (d) $14 \%$ & 6 & $16 \%$ & 0 & $0 \%$ & 2.924 & 2 & 0.232 \\
\hline $\begin{array}{l}\text { Hepatic } \\
\text { disease }\end{array}$ & 3 & 8\% & 0 & $0 \%$ & 0 & $0 \%$ & 4.61 & 2 & 0.100 \\
\hline Renal disease & 2 & $5 \%$ & 3 & $8 \%$ & 0 & $0 \%$ & 1.425 & 2 & 0.491 \\
\hline Gout & 3 & $8 \%$ & 2 & $5 \%$ & 0 & $0 \%$ & 1.494 & 2 & 0.474 \\
\hline Hepatitis C & 2 & $5 \%$ & 1 & $3 \%$ & 1 & $6 \%$ & 0.465 & 2 & 0.793 \\
\hline Dyslipidemia & 16 & $43 \%$ & 17 & $45 \%$ & 3 & $18 \%$ & 4.058 & 2 & 0.131 \\
\hline History of MI & 1 & $3 \%$ & 1 & $3 \%$ & 0 & $0 \%$ & 0.464 & 2 & 0.793 \\
\hline $\begin{array}{r}\text { GI (other than } \\
C D \text { ) }\end{array}$ & 10 & $27 \%$ & 14 & $37 \%$ & 0 & $0 \%$ & 8.297 & 2 & 0.016 \\
\hline $\begin{array}{r}\text { Hypothyroidis } \\
\mathrm{m}\end{array}$ & 5 & $14 \%$ & 0 & $0 \%$ & 0 & $0 \%$ & 7.86 & 2 & 0.020 \\
\hline $\begin{array}{l}\text { Baseline } \\
\text { DMARDS }\end{array}$ & & & & & & & & & \\
\hline MTX & 8 & $22 \%$ & 7 & $18 \%$ & 0 & $0 \%$ & 4.203 & 2 & 0.122 \\
\hline Prednisone & 6 & $16 \%$ & 8 & $21 \%$ & 4 & $24 \%$ & 0.487 & 2 & 0.784 \\
\hline SSZ & 5 & $14 \%$ & 2 & $5 \%$ & 2 & $12 \%$ & 4.013 & 2 & 0.134 \\
\hline Plaguenil & 2 & $5 \%$ & 2 & $5 \%$ & 0 & $0 \%$ & 0.949 & 2 & 0.622 \\
\hline
\end{tabular}


Previous TNF agent

$\begin{array}{cccccccccc}\text { Yes } & 13 & 35 \% & 20 & 53 \% & 9 & 53 \% & 2.76 & 2 & 0.252 \\ \text { No } & 24 & 65 \% & 18 & 47 \% & 8 & 47 \% & & \end{array}$

Origin

$\begin{array}{rr}\begin{array}{r}\text { Community } \\ \text { provider }\end{array} & 8 \\ \text { Another VA } & 1 \\ \text { facility } & 1 \\ \text { DoD } & 1 \\ \text { VASDHS } & 3\end{array}$

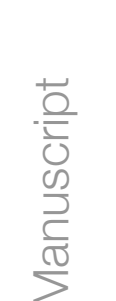

$\mathrm{RF}$ result at

baseline

TB test

Positive $\quad 7 \quad-\frac{\subsetneq}{>} 19 \%$

Negative $\quad 5 \quad .14 \%$

performed

\begin{tabular}{llll} 
& & \multicolumn{1}{c}{$c$} \\
\cline { 3 - 4 } Yes & 35 & $55 \%$ \\
No & 2 & $5 \%$
\end{tabular}

TB result

Positive 1 - $3 \%$

Negative $\quad 34 \quad 92 \%$

Hepatitis test

performed

$\begin{array}{lccc} & \text { Yes } & 31 & 84 \% \\ & \text { No } & 6 & 16 \% \\ \text { HsAg (+) } & & 9 & 24 \% \\ \operatorname{HsAb}(+) & & 1 & 3 \% \\ \operatorname{HcAb}(+) & & 5 & 14 \%\end{array}$

9

2

3

6

$\begin{array}{cc}3 & 8 \% \\ 8 & 21 \%\end{array}$

$4 \quad 24 \%$

$\begin{array}{lll}3.317 & 6 & 0.768\end{array}$

$2 \quad 12 \%$

$0 \quad 0 \%$

$3 \quad 18 \%$

$16 \%$

$\begin{array}{lll}2.279 & 2 & 0.320\end{array}$

$16 \%$

$33 \quad 87 \%$

$15 \quad 88 \%$

$\begin{array}{lll}1.369 & 2 & 0.504\end{array}$

$5 \quad 13 \%$

$2 \quad 12 \%$

$1 \quad 3 \%$

$31 \quad 82 \%$

$16 \%$

$1482 \%$

$31 \quad 82 \%$

$7 \quad 18 \%$

$12 \quad 32 \%$

$0 \quad 0 \%$

$25 \%$

$\begin{array}{rrccc}11 & 65 \% & 2.784 & 2 & 0.249 \\ 6 & 35 \% & & & \\ 6 & 35 \% & 0.449 & 2 & 0.799 \\ 0 & 0 \% & 1.33 & 2 & 0.514 \\ 0 & 0 \% & 2.457 & 2 & 0.293\end{array}$


*'Other" includes ulcerative colitis $(\mathrm{N}=5)$, uveitis $(\mathrm{N}=1)$, and spondylarthropathy $(\mathrm{N}=1)$.

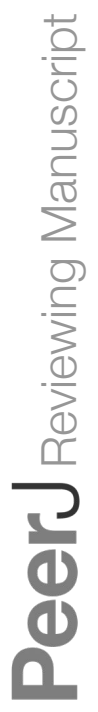




\section{Table 3 (on next page)}

Outcomes at the first follow-up visit and at 12 months for patients started on etanercept, adalimumab, and infliximab at the VASDHS, 2010-2011 


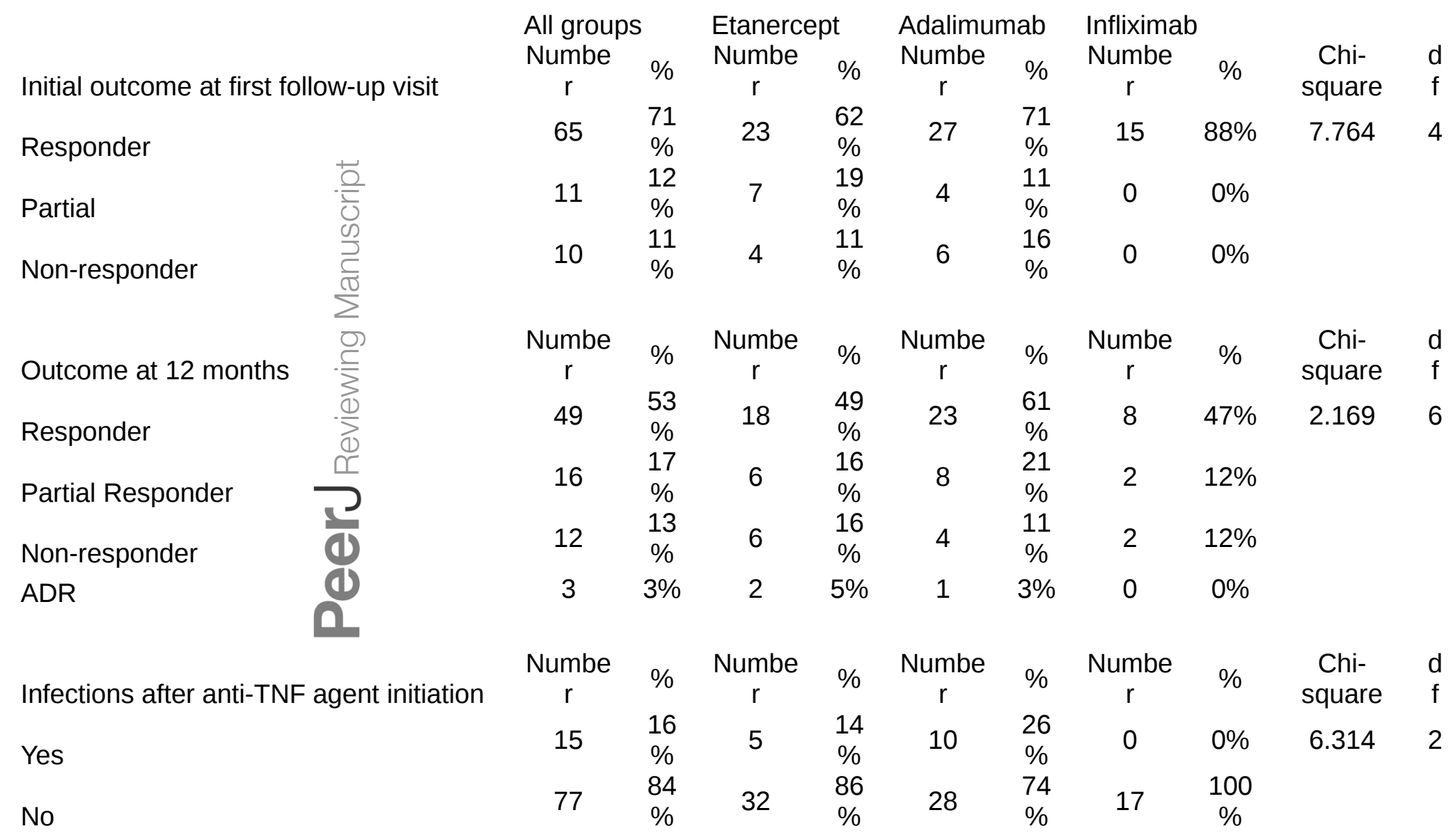




\section{Table 4 (on next page)}

Odds of responder relative to infliximab 
Crude analysis

Variable

$\begin{array}{cccc}\text { B } & \text { SE } & \text { OR } & 95 \% \mathrm{Cl} \\ -0.511 & 0.876 & 0.60 & 0.108,3.338 \\ 0.215 & 0.912 & 1.24 & 0.207,7.412\end{array}$

Etanercept

$\begin{array}{llll}0.215 & 0.912 & 1.24 & 0.207,7.412\end{array}$

Adalimumab

*Referent is Infliximab

**Hosmer-Lemeshow test, Chi-square $<0.0001, d f=1, P=1.000$

Odds of responder adjusted for age, gender, and TNF history relative to infliximab.

Variable

B SE OR $95 \% \mathrm{Cl}$

Etanercept

$\begin{array}{llll}-0.090 & 0.979 & 0.91 & 0.134,6.225\end{array}$

Adalimumab

$0.613 \quad 1.000 \quad 1.85 \quad 0.260$,

Age, years

$\begin{array}{llll}-0.064 & 0.024 & 0.94 & 0.895,0.983\end{array}$

Male

$\begin{array}{llll}0.351 & 0.919 & 1.42 & 0.234,8.600\end{array}$

TNF history

$\begin{array}{llll}-0.161 & 0.646 & 0.85 & 0.240,3.023\end{array}$

* Referent is Infliximab

${ }^{* * H o s m e r-L e m e s h o w ~ t e s t, ~ C h i-s q u a r e=9.670, ~} \mathrm{df}=8, \mathrm{P}=0.289$ 